\title{
LITERACY AND ORALITY: BETWEEN ABROGATION AND APPROPRIATION IN NGUGI WA THIONG'O'S THE RIVER BETWEEN
}

\author{
Bawa Kammampoal \\ Dr., Maître de Conférences, \\ Université de Kara, \\ Kara, Togo
}

\begin{abstract}
:
Colonizers have used language as an instrument of socio-political and economic control during colonisation. This has enabled them in the process to establish power hierarchy based mostly on linguistic superiority by undermining native tongues. In recent years, theories of postcolonial discourses hold the view that colonialism has fundamentally affected modes of representation of colonised spaces. Through questioning and travestying western hegemonic discourses, writers from once colonised spaces have challenged and subverted the hegemonic power of the colonial language by inserting different strategies into their own language to suit socio-cultural contexts. For postcolonial literary artists, this consists in taking the language of the former imperial power, to unlearn its worldview and re-place it in a discourse fully adapted to ones' own space and subsequently, produce new modes of representation in countering colonial canonical texts. In this sense, postcolonial discourse is crystallised by and replete with 'abrogation' and 'appropriation' in the canon of postcolonial studies. This suggests the writer's use of linguistic structure of the borrowed language, the manipulation of its syntactical structure as well as its semantics, to convey stance against the colonizer. In its pronouncement, an effort is made to advocate for a critical rethinking of the legacies of colonial domination as well as its accompanying epistemologies. Kenyan novelist Ngugi wa Thiong'o uses elements of oral tradition (orality) or better indigenous poetics in his fictional works, mostly The River Between, to express the meanings, feelings and experiences of his Gikuyu people. Thus, orality as a means of communication and carrier of the culture of those people to whom it is a mother tongue, has social, cultural, and political aesthetic roles to play in the African worldview. To achieve this, Ngugi employs historically significant events, moments and stylistic features which are characteristics of oral tradition to emphasise important key concepts that help to reconstruct positive moral values in conflict with foreign ones in a fragmented Kenyan society. Though many controversies surround Ngugi's writing and its medium of reception, this paper contends that his fictions written in his mother tongue or in English and/or translated into English, are part and parcel of his endeavour to appropriate the literary enterprise not only as a weapon of active physical revolt and textual indignation but also as against (post)colonial pathologies. Ngugi refashions the colonial English language to show that his country, Kenya, is not a mere passive
\end{abstract}

i Correspondence: email kammampoalbawa@yahoo.fr $\underline{\text { bawa kammampoal@yahoo.fr }}$ 
entity in tolerating colonial legacies; but challenges western hegemonic power dimensions, dismantles them to the point of bringing them under its own terms and conditions. The conceptual frameworks that underpin the study are New historicism (New Culturalism) and postcolonial theory.

Keywords: literacy, orality, abrogation, appropriation, Ngugi Wa Thiong'o's The River Between

\section{Introduction}

Developments in literature, oral as well as written, have recognised the quintessence of orality as a significant mode of communication in the socialization process and considered it as a powerful didactic tool. Psychologists, anthropologists, literary critics as well as experts, folklorists, creative writers have attested to the dynamism of orality (or orature) in the production and transmission of knowledge systems in literate as well as non-literate societies. This paper attempts to show how Ngugi wa Thiong'o has resorted to the African oral traditional paradigm of storytelling as a linguistic challenge in the context of postcolonialism to get his peculiar message across. These types of oral-narrative techniques, used in African traditional societies, have shaped the narration of events as well as moments in his fictional works. In fact, his novels are steeped in oral tradition as multi-layered texts with didactic and sometimes revolutionary functions. Ngugi wa Thiong'o, through his criticism, is known as a prominent cultural and literary theorist as far as the canon of postcolonial studies are concerned. In the 1960s, his critical insights made him become one of the leading advocate for a genuine critical rethinking of legacies of colonial domination as well as its accompanying epistemologies as can be found in texts like Weep not Child (1964), The River Between (1965), Devil on the Cross (1982), Decolonising the Mind: the Politics of Language in African Literature (1981), A Grain of Wheat (1967), Petals of Blood (1977), Homecoming: Essays (1972), Writers in Politics: Essays (1980), Wizard of the Crow (2007).

But in the early 1980s, as part of his advocacy for African languages in which he writes and produced literatures, he began writing in his indigenous Gikuyu language-a position and process outlined in the canonical collection entitled, Decolonizing the Mind: The Politics of Language in African Literature (1986) in which he contended that 'economic and political control can only be complete and effective if it is accompanied by mental control (1986: 16). His choosing to write in the Gikuyu language, to my mind, is to show that language is a medium of communication of ideas as well as feelings via conventional signs, sounds, or marks with distinguishable denotations and connotations. From this perspective, it is legitimate to assume that "Language has become an important means of understanding and interpreting human beings and aspects such as politics, religion, economics, social conflicts, class struggle and human condition" (Obi, 2003: 487-492). To a greater extent, when we talk about literature two factors are essential, a language and a human society that speaks the language, where the language is the medium of expression and the society, the provider of beliefs and manners which are expressed (Eme et al., 2011: 116; Kammampoal, 2010:267-278). For Edward Sapir, language is a purely human and non-human instinctive method of communicating ideas, emotions, and desires by means of voluntarily 
produced symbols and insists that "language does not exist apart from culture; that is from the assemblage of practices and beliefs that determines the texture of our lives" (Sapir, 1929: 221). In the same vein, Emenajo (2000: 1-10) argues that "language cuts through artifacts, socio-facts and mentifacts. Artifacts from the flora and fauna of cultural; sociofacts come from political, social, legal and economic structures, while menti-facts yield from language in its multi-dimensional realisations which are represented in ideas, beliefs, and oral and literary creativity". From Emenayo's critical insight one may argue that literature is clearly one of the menti-facts resulting from its employment of the decoding and encoding and constructing and reconstructing capabilities of language in the course of establishing reality, which is its object: for literature depends on language. In Black skin white masks, Fanon (1967: 18) warns "a man who has a language consequently possesses the world expressed-implied by that language".

Ngugi wa Thiong'o, Kenyan teacher, novelist, essayist, and playwright, sets his novel, The River Between in a claustrophobic locale rooted firmly in oral traditions. Oral traditions are messages that are transmitted orally from one generation to another. "Since traditional Africa was basically oral society... our history, science, medicine, technology, philosophy and literary forms were passed through words of mouth in myths, folktales, legends, proverbs, praise poetry and ritual performances" (Abdul Rashed Na'Allah, 1994: 101-118). Oral tradition makes it possible for a society to pass knowledge across generations without writing. "It is", writes Abdul Rashed $\mathrm{Na}$ 'Allah, "the main mode of transmitting knowledge and keeping records... and an important mode of education and communications in the continent" (1994: 101-118). It helps people make sense of the world and is used to teach children and adults about important aspects of their culture. In one word one may say that oral literature is the embodiment of African values and aspirations. From a literary perspective, we may say that Isidore Ikweho's assertions and postulations are relevant as to the hypostasis of orality in the life wire of oral as well written cultures in the African context. He sees oral tradition as a medium of : "acquir[ing] on a general or collective basis, information concerning themselves who they are, their origins and connection and the peculiar ways of living and behaving that identify them as a people and that must be preserved for the sake of continuity." (Okpewo, 1992: 115)

In this sense, it goes without saying that Ngugi's works function as an important link between the pioneers of African writing and the younger generation of postcolonial writers. After imprisonment in 1978, Ngũgĩ decided to abandon using English as the primary language of his writings in favour of Gikuyu, his native tongue. The transition from colonialism to postcolonialism and the crisis of modernity has been a central issue in a great deal of Ngũgĩ's writings.

Ngugi's recent publications, Globalectics: Theory and the Politics of Knowing (2012) and In the Name of the Mother: Reflections on Writers and Empire (2013), reflect firstly on a way to consider his primordial mission in contemporary conversations on world literature and secondly on decolonial thought in the last three decades of his literary career spent in exile. Ngugi seeks to understand the political, social, ideological, cultural and psychological operations of the colonialist on the colonised. He pondered the dual ideological forces which have on the one hand prompted the colonised to internalise the coloniser's values and on the other the subsequent resistance against oppression that ensued. He attempts to describe, study, analyse, justify, 
interpret and evaluate works of art of both the coloniser and the colonised so as to reformulate aesthetic and methodological principles on which a critic from once colonised spaces can evaluate a text. His findings suggest truth about the forces which at the same time promote and inhibit resistance which is as old as colonialism itself. In his endeavour Ngugi wants to show that oral tradition as a means of communication is fundamental in any attempt to define the nature of African literature no matter what definition given to it. The oral traditional impulse is all pervasive in African writing because its producers are variants of both literate and non-literate traditions. In this sense, one may argue that as a literary artist, Ngugi, a "synthesising artist" (Obiechina: 1992: 197-230) abrogates the Colonial imperial language so as to challenge the power structure which the imperial language has imposed on him and on his own people. The contention here is that both decolonizing the English language and writing in it is vital in its remodeling to reflect the rhythms and syntax of his native tongue. For him, this can reverse the assumptions of a privileged language and for that matter challenge the marginalization of local sentiments such as oppression, colonization, decolonization and neo-colonization.

In "Colonialist Criticism", Chinua Achebe states that, "we may write in English, for we intend to do unheard of things with it" (1975: 10). For Salman Rushdie, working in new Englishes can be a therapeutic act of resistance, remaking a colonial language to reflect the postcolonial experience. Thus, in "Imaginary Homelands", an essay he published in 1992, he contends that, far from being something that can simply be ignored or disposed of, the English language is the place where writers can and must work out the problems that confront emerging/recently independent colonies. Many post-colonial artists share the opinion that we can't simply use the language the way the British did (Achebe, 1975). For Rushdie, (1992: 17), it needs remaking for our own purposes or perhaps because we can find in that linguistic struggle a reflection of other struggles taking place in the real world, struggles between the cultures within ourselves and the influences at work upon our societies. To conquer English may be to complete the process of making ourselves free.

The paper, therefore, examines the extent to which oral literature can serve as a base for the development of a pedagogical model for instruction in an attempt to re-interpret the past within the framework of indigenous knowledge systems, epistemologies as well as philosophies to the younger generations using The River Between experience as an example.

\section{Theoretical Foundations: Abrogation and Appropriation}

The theoretical and scholarly debate about language used in the works of writers from once colonised spaces is addressed in detail in The Empire Writes Back (1989/2000). In this, the authors Bill Ashcroft, Gareth Griffiths, and Helen Tiffin explore the ways in which writers from once colonised countries encounter a dominant, colonial language. In this book, they carefully describe a two-part process through which writers in the post-colonial world displace a standard language -denoted with the capital " $\mathrm{e}$ " in "English" - and subsequently replace it with a local variant that does not have the perceived stain of being somehow a sub-standard one ; rather, it reflects a distinct cultural outlook through local usage. The terms they suggest for these two processes are "abrogation" and "accommodation". While they define "abrogation", the book 
tells us, as a refusal of the categories of the imperial culture, its aesthetic, its illusory standard of normative or correct usage and its assumption of a traditional and fixed meaning inscribed in the words used, "appropriation" is the use of the colonisers' language as a medium for the colonised of their own cultural experience. In other words, this means that abrogation refers to the rejection by post-colonial writers of a normative concept of 'correct' or 'standard' English used by certain classes or groups, and of the corresponding concepts of inferior 'dialects' or 'marginal variants'.

"Abrogation" is usually employed in conjunction with the term "appropriation", which, to some extent, describes the processes of English adaptation itself, and is an important component of the post-colonial assumption that all language use is a 'variant' of one kind or another -and is in that sense 'marginal' to some illusory standard. Thus, abrogation becomes an important political stance, whether articulated or not, and even whether conscious or not, from which the actual appropriation of language can take place. More than just the language, abrogation also sometimes offers a partial or total negation of Eurocentric assumptions about culture, history, and truth. In the process and in some cases postcolonial scholars and authors offer nuanced revisions of history or cultural assumptions in opposition to or as a form of sophisticated negation of the privileged and normalized Western norms.

In this seminal work, it has been argued that the crucial function of a language as a medium of power demands that post-colonial discourse as a canonical counter discourse defines itself by seizing the language of the centre and re-placing it in a discourse fully adapted to its originating colonized place. This can be done, they suggested, through two distinct processes. The first one, through the abrogation or denial of the privilege of 'English' which involves a rejection of the metropolitan power over the means of communication. The second one, is the appropriation and reconstitution of the language of the centre, the process of capturing and remoulding the language to new usages, marks a separation from the site of colonial privilege. The authors are careful to point out, however, that abrogation alone, though a vital step in "decolonizing" a dominant language is not sufficient at all in that it proffers the danger that roles will be reversed in the process and a new set of normative practices will move into place.

Another issue discussed by Ashcroft et al., about space concerned by the procedure and identify three types of linguistic communities: monoglossic, diglossic, and polyglossic ones. Monoglossic communities correspond roughly to old settler colonies where "English" -the lower-case " $\mathrm{e}$ " in "English" denotes local, non-standard/British usage- is the native tongue. A diglossic community occurs where bilingualism has become an enduring societal arrangement. India, Africa, the South Pacific and North America - where Québecois culture has created an artificially bilingual society- are cases in point. Finally, polyglossic societies"... [o]ccur principally in the Caribbean, where a multitude of dialects interweave to form a generally comprehensible continuum" (39). Since 'appropriation' in this context is the process by which the coloniser's language is made to "bear the burden" of one's own cultural experience ... Language is adopted as a tool and utilized to express widely differing cultural experiences (38-39 and has for that matter, become a vital moment in the de-colonizing of the language and the writing of 'English'. But it is fact that without the process of appropriation the moment of abrogation may not extend beyond a reversal of the assumptions of privilege, the 'normal', and correct inscription, all of 
which can be simply taken over and maintained by the new usage. Appropriation is the process by which the language is taken and made to 'bear the burden' of one's own cultural experience, or to 'convey in a language that is not one's own the spirit that is one's own. (Rao 1938: vii quoted in Bill Ashcroft et al., 1989, 2000). For Raja Rao, language is adopted as a tool and utilized in various ways to express widely differing cultural experiences. These differences may exist in cultures which appear to be quite similar. For in one sense all post-colonial literatures are crosscultural because they negotiate a gap between 'worlds', a gap in which the simultaneous processes of abrogation and appropriation continually strive to define and determine their practice.

In the face of the controversies surrounding the writings of the East African writer Ngũgĩ wa Thiong'o, this article contends that his Gikuyu fictions (also in English translation) are as much an integral part of his engagement with the Anglophone tradition as his earlier works published in English. Negotiating through various critical issues raised on Ngũgĩ and his articulations on the language of African literature, the paper uses The River Between to show that those originally written in English and those in Gikuyu benefit from similar processes of translingualism and addresses the subject of the relationship between translation and minor languages, arguing that translation(from mother tongue or vice versa) involves an inevitable and continuous manipulation of texts in which the words' subjectivity, ideology, visibility and power complicate the very process of translation and reception of texts from local minor languages to major coloniser's languages. Finally, the paper shows that Ngũgĩ's Anglophone and Gikuyu novels (in translation) are complementary in the exploitation of various manifestations of translingualism, despite arguments to the contrary.

The River Between abrogates standard English language, in subtle and more pronounced ways. In Ngugi's literary world, he strokes, scrutinizes and satirizes all societal institutions: politics, the school, the church, economic, administration and all colonial legacies in society. In essence, because of its congenital condition of being born out of colonial experience, postcolonial literature is bound to be obsessed with the questions of power and resistance. So be it Marxist ideas of the expansion of economic power through means of political coercion and ideologically grounded suppression of the proletariat classes or Foucaldian ideas of systematic circulation of discourses for acquisition of power; or, be it is the endless contest of power and resistance in the colonial context or the postcolonial and neo-colonial ones it can be argued that almost all postcolonial writers have betrayed a very strong propensity in their endeavour to unravel and dissect, within the larger social fabric, the complexities around which political, economic and cultural dominance is made possible. In this paper, I intend to examine the rejection of a standard English language by post-colonial writers, mostly Ngugi wa Thiong'o, in his effort to show that colonisation in all its different facets, forms and articulations, is not only physical but is also mental. McLeod (2000: 33) opines that the rule of British Empire did not only depend on military and physical force only. According to Bill Ashcroft, Gareth Griffiths, and Helen Tiffin postcolonial literature is written out of a tension between 'abrogation' and 'appropriation' and provides suggestive lists of appropriation and abrogation footnotes on English which include: untranslatable words, code mixing and code switching, vernacular words to interrogate European discourses, mostly the ones that 'degrade and deny our humanity'. 


\section{Aesthetic Principles in Ngugi wa Thiong'o: Thoughts and Approach}

Before we get started on pointing out the instances of abrogation and appropriation in Ngugi wa Thiong'o's writing, let us have once again a brief discussion on what abrogation and appropriation are, how and most importantly why they emerged. This is not a repetition but is worth recalling that abrogation and appropriation, as was said earlier on, are both postcolonial quintessential literary phenomena. In general terms 'abrogation' means 'the repeal or abolition of a law, right, or agreement'.

But in the light of postcolonial literature, 'abrogation' means the colonised rejecting the coloniser's language imposed on him/her as the medium of writing, especially in literature and the arts. This phenomenon emerged from the sense of identity and self and was a form of protest by the colonised against the coloniser. Almost all the writers from the colonised countries wanted to expand their literature and cultural values in their own language or mother tongue as a sense of identity. This has been the case of Africa and Indian, to mention just a few. To wit, many writers from these colonised spaces switched to their own regional languages or mother tongues leaving English, the coloniser's language. A language that was that of their British colonisers. In Africa, Ngugi among others, was at the vanguard. A significant sign of his abrogation of European expectations and traditions was his refusal in 1977 to write in the English language, using instead Gikuyu, his own Kenyan language to voice his thoughts and people's experience. This came as a result of a conscious rejection of the language of the British coloniser and a decision to write in the language of ordinary Kenyans to the detriment of the local Britisheducated elite.

In fact, a year earlier, Ngugi was involved in creating a community theatre for his village, Karmiriithu. Both Ngugi wa Thiong'o and Ngugi wa Mirii provided the script for the community play. But when the working session started for two months, unexpectedly the peasants reworked the script by adding much to it and altered the language substantially to make it carry their experiences and the feelings adequately. In the end, the play which came to be known as Ngahika Ndeenda was quite different from the script provided by both writers. The result is that he was sent to prison. On this process of abrogation and appropriation by the peasants, Ngugi writes in Detained: A prisoner's Notes (1981: 78):

"For myself, I learnt a lot. I had been delegated to the role messenger and a porter, running errands here and there. But I had time to observe things. I saw how people had appropriated the text, improving on the language and the episodes and metaphor, so that the play which was finally put on to a free paying audience on Sunday 2 October 1977, was a far cry from the tentative awkward efforts originally put together by Ngugi and myself..."

In the same line of thought, Ngugi overtly admits: "I learnt my language anew" (1981: 76). As one of the most radical among those writers who have chosen to turn away from English, Ngũgĩ wa Thiong'o, a Gikuyu writer from Kenya, began a successful career writing in English, the language of the center, before turning to work entirely in his native language. In Decolonising the Mind, his 1986 "farewell to English," Ngũgĩ posits that through language people have not only 
described the world, but also understood themselves by it. For him, the use of a foreign language in Africa is like a "cultural bomb" which sustains to the fullest a dangerous process of erasing memories of pre-colonial cultures and history and gradually installs the dominance of new and more insidious forms of colonialism. Writing in Gikuyu, then, is Ngũgĩ's way not only of harkening back to Gikuyu traditions, but also of acknowledging and communicating their continuing presence in a competitive world. Primarily, Ngũgĩ is not only much more concerned with universality, although models of struggle can always move out and be translated for other cultures, but is with preserving the specificity as well as the peculiarity of individual groups. In a general statement, Ngũgi makes this point clear when he points out that language and culture are inseparable, and therefore, the loss of the former results in the loss of the latter :

"a specific culture is not transmitted through language in its universality, but in its particularity as the language of a specific community with a specific history. Written literature and orature are the main means by which a particular language transmits the images of the world contained in the culture it carries. Language as communication and as culture are then products of each other... Language carries culture, and culture carries, particularly through orature and literature, the entire body of values by which we perceive ourselves and our place in the world... Language is thus inseparable from ourselves as a community of human beings with a specific form and character, a specific history, a specific relationship to the world." (1986: 15-16)

But in the process no sooner had the tenants of postcolonial literature started espousing the philosophy of abrogation and appropriation than it became clear that 'the sense of abrogation' was more like an emotional impulse than a practical thoughtful step. The immediate impact of this epistemology was cutting down their reach to their audience. But the incumbent tenants of this concept had the responsibility to tell and complain about the coloniser's inhuman deeds such as torture, hypocrisy, insults, plunders, exploitation to the rest of the world. For this reason, they needed a language as a medium which could reach as many people as possible, and a language like that of the coloniser had its own advantage for this purpose. And yet, they did not want their own taste and culture to be lost forever.

From the foregoing ambiguity emerged another epistemology called 'appropriation'; a process through which the coloniser's language merged with the colonised people's content or sociocultural realities. This pushes one to argue that 'appropriation' stands out as transferring the spirit of the colonised people's language to that of the coloniser's and making the coloniser's language communicate the spirit of the colonised people. This brought about to some extent much controversial issues and heated debate regarding appropriation right from its germination or inception. The fact of the matter remains that when it came into use and because of its unquestionable ability to adapt to changing times and conditions, it gained momentum as a token of open-mindedness. But opinions were divided on this. What emerges is a certain shared set of concerns. Despite the diversity of trends or opinions, there is no doubt that appropriation and abrogation were deemed to pose direct and serious challenges to the colonial centre from the colonised margins by negotiating new ways of arguing that both epistemologies contested; 
the dominant mode and thereafter gave voice and expression to the colonised or once colonised peoples.

It is also worth of mention that post colonial literatures were deemed actively engaged in the act of "decolonising the mind" (Mcleod, 2000: 28) as understood by Aschroft et al. Inspired by Rushdie's argument about the need to decolonise the English language, Aschroft et al. have in their seminal book The Empire Writes Back orchestrated many controversial issues pertaining the quintessence of the postcolonial canon into a coherent critical practice. This book, in its articulations and epistemologies, epitomises the increasing popular view that discourse in the once colonised countries was fundamentally concerned with "...challenging the language of the colonial power, unlearning its worldview, and producing new modes of representation"(Mcleod, 28). This book has thoroughly examined the fortunes of the English language in countries with a history of colonialism, noting how writers were expressing their own sense of identity by refashioning English in order to enable it to accommodate their experiences. In this respect, Chinua Achebe (1975: 61) is natural when he writes that,

"The price a world language must be prepared to pay is submission to many different kinds of use. The African writer should aim to use English in a way that brings out his message best without altering the language to the extent that its value as a medium of international exchange will be lost. He should aim at fashioning out an English which at once, universal and be able to carry his peculiar experience. I have in mind here the writer who has something new, something different to say. The non-descript writer who has little to tell us, anyway, so he might as well tell in a conventional language and get it over with." (Emphasis mine)

From this argued point, it becomes crystal clear that the English language was being displaced by "different linguistic communities in the postcolonial world" (Mcleod, 2000: 8) in an attempt to challenge the colonial value system, it enshrined, and depict these communities' sense of cultural difference. In a tone more prescriptive than descriptive, they expressed the belief that the crucial function of language as a medium of power should be the precondition to postcolonial writing in an attempt to define itself by seizing the language of the centre and replacing it in a discourse fully adapted to the colonised place (2000: 38). Aschroft et al. claim that the refashioning of the language of the center should be done through various strategies by writers of colonised or once colonised nations by "inserting untranslatable words into their texts, by glossing seemingly obscure terms, by refusing to follow standard English syntax and using structures derived from other languages, of incorporating many different creolised versions of English in their texts". For them, each of these strategies was demonstrated as operating in a variety of colonial texts, and in each the emphasis should be laid on the writers' attempt to subvert and refashion standard English into various new forms of 'English' as a way of jettisoning the colonialist values which standard English housed. Thus, The Empire Writes Back asserts that postcolonial writing was always written out of the 'abrogation' (discontinuing) of the received language, English in particular, which speaks from the centre and the act of 'appropriation' (seizure) which brings it under the influence of a vernacular tongue, the complex of speech habits which characterise the local language (Aschroft et al., 1989, 2002: 39). The new English of the colonial place was ultimately 
irredeemably different from the language at the colonial centre, separated by an unabridgeable gap: "these absence, or gap, is not negative but positive in its effect; it presents the difference through which an identity (created or recovered) can be expressed." (Aschroft et al., 1989, 2002: 62).

In Ngugi's understanding the English language is the instrument of colonisation which was "the most important vehicle through which that power fascinated and held the soul prisoner. The bullet was the means of the physical subjugation. Language was the means of the spiritual subjugation" (Ngugi, 1988: 9). Achebe's subversion of the colonial language lies in his use of the English language and the western narrative tradition (the novel as an art form) for the purpose of conveying the African story to the world though there are claims that non-African languages cannot accurately express African experiences and sensibilities. For writers from once colonised spaces, African writers in particular, the issue of rejection and subversion of the Coloniser's language is a major part in defining African literature. Ngugi's use of linguistic structure of the English language, his manipulation of syntactical structure, as well as its semantics enables him to convey his stance against the colonizer and his downgrading of the blacks and as well show that his story is didactic and instructive: in other words, it is a documentary one. Ngugi's concern is to try to reform European ideas about the African experience by using the colonizer's language to express his own ideas and reform African ideas about African experience.

In Orientalism (1978) Edward Said, the Palestinian literary and cultural theorist, has pointed out how colonialism institutionally created a wide range of knowledge which supported the divisive practices of colonial government of settlement. Drawing upon developments in Marxist and postructuralist theories of power structures, particularly the political paradigms developed by Antonio Gramsci and France's Michel Foucault, Said carefully examines how knowledge presented as scientific truths ranging from mystic place of exoticism, moral laxity to sexual degeneration which Western powers formed about colonised spaces gradually contributed to justify their subjugation and domination among other things. Postcolonialism is a process of overturning the dominant ways of seeing the world, and representing reality in ways which do not replicate colonialist values. In this sense, if colonialism means colonising the mind, then meaningful resistance to it requires, in Ngugi's phrase "decolonising the mind" (McLeod, 2000).

Decolonising the Mind (1981) is Ngugi's attempt to examine how the mental space of colonized peoples came to be strangely invaded and appropriated by the coloniser. It is considered a significant seminal text on how language can be manipulated and pressed into the service of power. This book and his subsequent works, both fiction and nonfiction, set Ngugi apart as a forceful advocate of total decolonization, not only of the more visible political and economic sphere, but also of the mind. In his assertions and postulations, he ruled the fact that there were few African writers of international note producing work in their native languages, and accordingly struck out to publish books only in Gĩkũyũ or Swahili. In so doing, he believed that translation could be a fine bridge between cultures. But in the course of events, he also gets to understand that each particular language, each dialect, had a distinct musicality that will be lost in the translation process, and will be forever lost was the language to die as well.

The effect of this was immediate. In fact, Ngugi's play written in Gikũyũ, as was said earlier on, had been critical of the regime of Jomo Kenyatta. In fact, it depicted the leadership as 
an elitist one which is far removed from the Kenyan peasantry whose interests it claimed to champion though and was even responsible for the acceleration of the acute economic inequalities that persisted long after independence. The political leaders who had been at the vanguard in the anticolonial struggle had decided to jail him because of his use of the vernacular to threaten their leadership by speaking directly to the masses, not to the literate in English, thereby prompting not only the anticolonial struggle but also the neo-colonial one. The irony here is that, the earlier books he had written before in English had similarly taken aim at lashing postcolonial powerholders, "So even after they inherited the flag, their mental outlook, their attitudes toward their own societies, toward their own history, toward their own languages, toward everything national, tended to be foreign; they saw things through eyeglasses given them by their European bourgeois mentors". This is the message of Moving the Centre: The Struggle For Cultural Freedoms, a collection of essays published in 1993, which to my mind, was even more seditious.

In some ways, literacy is consequently emphasized over orality and contextuality. But recent developments in the academia, however, have tended to emphasize the supremacy of orality as a preferred mode of socialization with accurate pedagogical functions. Anthropologists, literary critics, folklorists, creative writers and even psychologists all attest to the dynamism of oral literature in the production and transmission of knowledge systems not only in Africa but generally in pre-literate societies all over the world. This is much a challenge to those from both colonised and the colonising nations' (Mcleod, 2000: 25). Thus, Ngugi wa Thiong'o's first novel, The River Between, is fraught with African aesthetics which translate the revolutionary impulse to unveil the multi-layered source of constraints which impedes Africa's rich literary traditions as part of its cultural heritage in boosting up the rebel spirit of his people against colonial and neo-colonial powers. Most of his novels are written with the intent to show that they are the outcome of interaction between oral storytelling and western type of narrative style in portraying the sociocultural developments in African society from pre to postcolonial era. In The River Between, Ngugi strategically employs historically moments and events in the lives of his characters in linking them with myths, legends and folktales drawn from oral tradition. In African writing, one cannot fully appreciate the works of Chinua Achebe, Ngugi wa Thiong'o, Camara Laye, Ousmane Sembene and Amos Tutuola, just to mention a few, without placing them into the context of Africa's classical period, its oral tradition. Some of the earliest writers derive their inspiration from traditional lore, indigenous customs, and the oral tradition, in a bid to demonstrate to their readers, African and non-African alike, that Africa has a culture she could be proud of (Palmer, 1976 : pix). Despite the impacts colonialism made on African literature, African writers with abrogation and appropriation have adapted alien traditions and made them their own by placing them into African classical frameworks. Although there have been various and contending opinions about the reliance of postcolonial literature on English language, it is logical to argue that in the choice of appropriated/unappropriated English for writing the postcolonial experience is an effective counter strategy against a continued attitude of servile inferiority. Ashcroft et al in the Post-Colonial Studies Reader give expression to this dilemma in the following words: 
"There are several responses to this dominance of the imperial language but two present themselves immediately in the decolonizing process-rejection and subversion. The process of radical decolonization proposed by Ngugi wa Thiong'o is a good demonstration of the first alternative. Ngugi's programme of restoring an ethnic or national identity embedded in the mother tongue involves a rejection of English, a refusal to use it for his name, a refusal to submit to the political dominance its use implies...However, many more writers have felt that this appeal to some essential cultural identity is doomed to failure, indeed, misunderstands the heterogeneous nature of human experience." (1995: 283)

In Oral Tradition and the Contemporary Theatre in Nigeria, (Adedeji, 1971:2) oral tradition is defined as a "complex corpus of verbal or spoken art created as a means of recalling the past... and is based on the ideas, beliefs, symbols, assumptions, attitudes, and sentiments of a people". This definition is not far-fetched when we refer to the works of Ruth Finnegan (1976), Isidore Ikpewo (1990), Adeboye Babalola, Abubakar Dandatti, Olaitan Olatunde, William Echezona, Oludare Olajubu and Abdul Rasheed Na'Allah which not only give us hints on oral tradition but also on the various forms, nature as well as functions of African literary resource and discourse. Ngugi's first novel, The River Between, stands out as a case in point. As a matter of fact, this definition not only gives us insights into what oral tradition entails but it also makes sense to say that its functional role is put it into the limelight. So, the contribution of forms of oral tradition namely myths, legends, songs, proverbs, philosophies, rituals, etc., sharpens the style and greases the themes of the novelist. In Ngugi's writing he uses historically significant moments in the lives of his characters which he interweaves with myths and legends drawn directly from oral tradition to show that myths have always a cultural, political and social agenda. Myths as well as legends are traditional stories which hold special significance to a group or culture. They are passed down through the generations by word of the mouth. Ngugi's use of myth is not only used in the text as a political instrument whose role is to convey an ideology but is also used to romanticize and glorify an historical era. For him, Gikuyu myths have a special cultural, political and social agenda. In general terms, this is so because "a culture in part consists of a stockpile of accumulated stories upon which writers rely and which are crucial to the constitution and negotiation of power within the culture" (Ryan, 1999:130). As myths and heroes change throughout time, so do the popular beliefs about these heroes. As is the case with the oral tradition, written literature, in this sense, is but a combination of the real and the fantastic. It not only combines the real or the contemporary world, and history, the realistic world of the past, but it also uses myth and hero, with metaphor as an agent of societal transformation. In other words, the novelist mixes on the one hand, the contemporary world and the realistic world of the past since literature, written or oral, is atomized and fragmented history: This is the alchemy of literary experience.

Transformation, in this sense, is the crucial activity of a story and constitutes in itself, its dynamic movement. This enables the creative writer to better examine the relationship between the reader with the world and with history. The writer in the process of examination, invents characters and events that correspond to history but are not really history. Most of the time, at the centre of the story is myth, the fantasy element, a character or event that moves beyond reality, though it is always rooted in the real. For Vuiningoma as quoted by Cloete and 
Madadzwe (2004: 27-44), Ngugi in his writing establishes "an oral universe" that carries the reader into a world of magic, spiritual and mystical powers with myths and legends... integrated into the text. Thus, Chapter I opens with myths and legends drawn directly from his oral tradition. This chapter creates an oral universe by telling the story of a longstanding rivalry between two opposing ridges, Makuyu and Kameno, which is partly due to historical and mythological background. In fact, Makuyu and Kameno are two ridges separated by a life-giving river called River Honia where 'men, cattle and wild beasts' came to quench their thirst. The river separates and binds the tribe at the same time. Its life-giving qualities lies in the fact that Christians as well as traditionalist use the same river for their purification rites. Kameno was the stronghold of the Christians whilst Makuyu was the home of the pagans. In a tone characteristic of an oral one, the novelist relates the myth of the land, where under a fig tree, Gikuyu and Mumbi, the ancestral parents of the land and Murungu, the almighty God, has given them the land to till. Kameno has been the place where the father and the mother of the tribe have been given the land and for that matter has assumed spiritual superiority over the Christianised Makuyu. Thus, Kameno hosts the origins of the seers of old, the great prophets such as Mugo wa Kibiro, Kamiri and Wachiori, mythological figures in one word.

Originally entitled The Black Messiah, The River Between (1965) is Ngugi's first novel though it was published second to Weep not Child. The novel is set in precolonial Kenya. The first elements of oral tradition found in the story are myths and legends which belong to the group of narratives generally referred to as tales and which are very important to the overall understanding of the novel in the African context. The story is both messianic and legendary: first of all, it is messianic in that it traces the origin of a prophecy by Mugo wa Kibiro, the great Gikuyu seer of old (1965: 3) that envisions the emergence of a messiah from the hills to save the people from colonial yoke. For instance, Waiyaki's father, Chege, believes his son is the chosen one to lead the people out of bondage by using archaic lexical items to tell his son : "Arise! heed the prophecy"... (1965: 22-24).

To "heed the prophecy", he needs formal education which is an important instrument that can enable him fight for sociopolitical and economic independence. In an interview with Abdulai as published by Dennis Duerden (1972/1975: 126), Ngugi explains that "schools have always associated education with advancement, with political freedom, with even economic freedom... [the people]... have always seen education as a means to greater prosperity...". The story suggests that his effort to get himself educated at Siriana, his exposure to Christianity and the white mans' ways have not only alienated him in the process from his own people but have also given him different values that have cut him from his own background. In the long run he notices that exposure to the white man's ways cannot help him bring the people together : conciling both ridges. He is rejected from his own people on the grounds that he is not ready to liberate the land from the shackles of poverty though he has good intentions about the establishment of an affordable education for his people. Secondly, the story is legendary. This is observed by Killam. In his $A n$ Introduction to the Writings of Ngugi (1975), he writes :

"Waiyaki is part of the legend of his people and Ngugi presents him in folkloric terms by exploiting similarities between the role he is assigned to play as a saviour that of the biblical 
Christ, against a legendary history which reveals a strong association between Gikuyu and Christian creation of myths" (33).

Here it is very important to note that both myths and legends make the novel rely heavily on Gikuyu traditional lore and for that matter acts as folkloric elements contained in indigenous storytelling modes in the text in general. In general terms, the text deals with the conflict of cultures: the conflict between two opposing groups within a single tribe, as was said earlier on, one of which lives in Makuyu and the other in Kameno. This conflict has its roots deep in the history of the tribe and is given a modern tinge. Thus, western ideas as opposed to traditional ones is the subject matter. With these oral elements, legends and myths, Ngugi wants to show that the great periods of literature drew on the order of ideas and images established firmly by orality through which its growth expresses itself as part of the general imagination of that society. In this sense history becomes a living tissue in the narrative or text. The narrator tells his story: "And Murungu had told them: 'This land I give you, o man and woman. It is yours to rule and till, you and your posterity' (2); so, the land is worth fighting for with the help of some spiritual leaders such as 'Mugo, the geat seer, Wachiori, the glorious warrior and Kamiri, the powerful magician' (1965: 3) whose warnings the people refused to listen to. In fact, the pantheon of the gods and spirits of the Gikuyu culture are but a few of the more examples on the continent. Africans depend for their power and identity on orature. In the oral tale all these are complex fantasy characters which are refracted in written literature.

Pointing at the Magumo tree and the mysterious bush around it, Chege tells his son Waiyaki about the history of the tribe in simple and lucid language:

"That is a blessed and sacred place. There, where Mumbi's feet stood, grew up that tree. So, you see it is Kameno that supported the father, and the mother of the tribe. From here, Murungu took them and put them under Mukuruwe Wa Gathanga in Muranga. There our Father and Mother had nine daughters who bore more children. The children spread all over the country, some came to the ridges to keep and guard the ancient rites..." (1965: 18)

The two ridges are reflected in the image of the 'two lions'. There is an underlying irony here because when one views the ridges from the valley one sees the ridges as antagonistic to each other because of the way in which they seem to stare at each other. Another ironic unity-indivision symbol is the Honia river which not only means 'cure' but is also referred to as the 'soul' of the ridges, giving life to all things in Ngugi's fictional world. The novelist presents the 'river' as a source of life and a symbol of growth. When separation comes between the two ridges, the church in Makuyu draws inspiration from Honia, while the traditional religion is celebrated on its bank. In chapter IV of the novel, Ngugi tries to show that the antagonistic relationship that exists between both ridges is artificial. When Chege and his son, Waiyaki, climbed the hills, they realised what they had looked like and wondered how his ancestors managed to tame the land. The narrator explains: 
"The ridges slept on. Kameno and Makuyu were no longer antagonistic. They had merged into one area of a beautiful land, which is what, perhaps, they were meant to be. Makuyu, Kameno and other ridges lay in peace and there no sign of life, as one stood on the hill of God" (1965: 16)

"They must have been great and strong to have braved the hazards of the forest" (10) to settle there. Sometimes in the bush, Waiyaki and the other boys staged and played the myth of Demi na Mathati. Legends have it that Demi na Mathathi were giants of the tribe who have lived a long way back at the beginning of time. On their arrival, they cut down trees and cleared the dense forests for cultivation. They owned many cattle, sheep and goats and often sacrificed to Murungu so as to be in communion with their ancestral spirits. Waiyaki had heard about these two generations of the tribe and he was proud of them... (10).

In an exchange with one of the boys from a village called Konia with whom he often plays and discusses some issues pertaining the quintessence of some cultural values, the boy expressed much concern about Waiyaki's being eligible to act as 'Demi':

"You cannot be demi'.

'Why?' he asked. The other boys came round. 'You are not ready for circumcision. You are not born again.' Waiyaki looked at the ground and felt small." (10).

In the tribe, it is an axiom that the only way for someone to be considered a fully grownup (man or woman) is to be circumcised as soon as one reaches puberty. That is what is called the "second birth". Those who are not circumcised are not only allowed to do any significant work or marry; but are also basically banished from doing many activities. In fact, they are looked down upon. This ritual thus plays a crucial role in preserving the social bond that keeps the tribe together. According to the Gikuyu custom, it is only after the "second birth" shall Waiyaki be treated as a grown up and be entiltled to being told all the secrets of the land. So immediately after Waiyaki's second birth Chege took him to the bush to teach him the secrets of the tribe. First of all, he taught him tribal knowledge by showing him the virtue of plants, in other words the medicinal values of various plants and roots. Secondly, he told him a story about male chauvinism when they found an antelope running away for her life. Chege tells his son: "They see men and run away". (18) Waiyaki was very puzzled and asked, "Don't they run away from women?"

Then Chege narrates the story of how matriarchal families descended from nine daughters of Gikuyu and Mumbi and were changed to the patriarchal order :

"Long ago women used to rule this land and its men. They were harsh and men began to resent their hard hand. So, when all the women were pregnant, men came together and overthrew them. Before this women owned everything. The animal (antelope) you saw was their goat. But because the women could not manage them, the goats ran away. They knew women to be weak. So why should they fear them?" (18). 
In chapter Nine of the novel, Chege appears to the reader as the epitome of the true and genuine Gikuyu patriarch because he is presented to the reader as one of Gikuyu's wisest men who knew all the ways of the tribe; all the secrets and prophecies of the ancestors. With the status of a seer, he was the first to predict the arrival of the white man. But his prophecy fell on deaf ears. Nobody listened to his warnings as to the coming of the white man and the strategies to withstand him. Very tired of preaching in the desert, he decides to use another strategy which consists of acquainting oneself with the ways and secrets of the white man and using them to fight him.

"I wrote The River Between first. I had come from a missionary school and I was deeply Christian... In school I was concerned with trying to remove the central Christian doctrine from the dress of western culture, and seeing how this must be grafted on the central beliefs of our people. The River Between was concerned with this process." (Ngugi, 1966).

In the above quotation, it is crystal clear that just like so many of the institutions that Europeans gave to the colonies were seen by its founding patrons as a benevolent as well as a civilizing instrument for the colonised Africans. Its medium of instruction was the English language and this was detrimental to the children who spoke only the local Gĩkũyũ tongue. Since the English language was the language of command, power, rationality, and intelligence, Gĩkũyũ language signified backwardness - an Africanness in one word. The impact of this on Ngugi was immediate as he himself has attested. Since the novel as a western artefact, is intended for both African and non-African readers, Ngugi uses English as his medium of expression. He uses very simple and lucid languages throughout the narrative and his characters speak in plain simple English in their exchange. One can hardly make any distinction between the language of a village elder like Chege, Joshua and educated youngsters like Waiyaki or Nyambura. Since he was the product of the colonial school, his Christian faith obliges him to use symbols, paradox, parallelism, allegory, allusions and images tinged with biblical aura or language. Chege also refers to the White men as butterflies. Yet another major ironic symbol in the novel is Ngugi's use of Christian and Gikuyu myths. Ngugi uses the close similarity between the biblical adamic myth to those of the Gikuyu and Mumbi in his Gikuyu culture. He contextualises this in the fight for the recovering of the land and the freedom of the people. Thus, Murungu, the Gikuyu deity assures Kameno just as God (Yahweh) assures Adam and Eve that the land is their property and is worth fighting for. "This land I give to you, o man and woman. It is yours to rule and till you and your posterity" and it belongs to them forever: it is their birthright. This also echoes in Weep not Child to show the spiritual and physical associations attached to the land. The narrator puts Chege's warnings this way: "Chege had told the people of the ridges what had happened in Muranga, Nyeri and Kiambu...of Tumu Tumu, Gikuyu, Limuru and Kijabe" (7). The strongest thing about all this is that the butterflies are seizing lands and are "putting many houses and some taking the land" (7). "For he saw many butterflies, of many colours, flying about over the land, disrupting the peace and the ordered life of the country" (20). Then, "he cried aloud and said there shall come people with clothes like butterflies'. "Butterflies disturbing the people." 
Mugo, just as Isaiah, also prophesies of the coming of a Messiah who is yet to come to save the Gikuyus using a biblical language:

"Salvation shall come from the hills. From the blood that flows in me, I say from the same tree, a son shall rise. And his duty shall be to lead and save the people" (20).

The character of Waiyaki emerges as that saviour. Chege tells his son, Waiyaki, his responsibility as a saviour the following dialogue on page 21:

\footnotetext{
"You have heard of Mugo wa Kibiro ?"

'Yes'

'He was a seer...he saw things... the future unfolded before his eyes...'

He further continues to show Waiyaki that they are the direct descendants of the seer:

"We are his offspring. His blood flows in your veins".

Waiyaki stood as if dumb. The knowledge that he had in him the blood of this famous seer, who had been able to see the future, filled him with an acute sense of wonder" (1965: 21).
}

The influence of the Christian doctrine on Ngugi in his handling of the theme of saviour is appalling. Ngugi through the character of Joshua and preachers extensively quotes passages from the Holy Bible they preach to their flock :

\footnotetext{
"Behold, a virgin shall conceive,

And bear a son,

And you shall call his name Immanuel" (29).
}

Isaiah, the white man's seer, had prophesised of Jesus. He had told of the coming of a messiah. Had Mugo wa Kibiro, the Gikuyu seer, ever foretold you of such a saviour. No. Issaiah was great. He had told of Jesus, the saviour of the world' (29). Let not your heart be troubled: Yes, believe in God, believe also in me. In my father's house are many mansions: If it were not so, I would have told you. I go to prepare a place for you.

Both Waiyaki and Joshua are considered as saviours by their flock or followers. Joshua, Nyambura's father, "renounced his tribe's magic, power and ritual" (29) to become a fanatic Christian. Waiyaki, Chege's son, cannot eschew his father's ways worshipping Gikuyu gods namely Murungu, Mweenanyaga, Ngai (29) and become completely a Christian. The novelist presents them as uncompromising adepts who demonstrate their faith with enthusiasm and dedication. For Joshua, those who refuse Jesus are the children of darkness. "These are the sons and daughters of the evil one, will go to hell; They will burn and burn forever more, world unending" (29). Christians and the unerring white man had called "the Gikuyu god the prince of darkness" (29). Joshua thinks about the sufferings of Job, a biblical figure whose faith God tested by making his wife miserable. This novel is full of allusions to the Biblical myths and legends: Christianity, sin, born again, redemption, prayer, Jesus and God. It should emphasised that the us of biblical language by Ngugi is not meant to downgrade originality in oral discourse, but is appropriate 
in tilling the theme of a people living in bondage in their attempt to liberate themselves and thereafter recover the lost lands.

Though Ngugi does not use proverbs profusely, there are some instances where the novelist uses proverbs give local colour to some events and actions. Thus, we are told that Waiyaki's fame "spread like a fire in a dry bush". In another instance, we are told that to his competing friend Kamau, Waiyaki appears as 'the hawk that always snatched his piece of meat'. Thus, the old Gikuyu seer, Mugo Wa Kibiro warns the people: "There shall come a people with clothes like butterflies". Ngugi employs short and terse sentences in his effort to vividly describe scenes and incidents and his strong narrative style heightens suspense and drama in the novel. Gikuyu words and phrases are used sparingly in the novel and must be noted that the meanings of such Gikuyu words are given at random in the phrase immediately following them. For instance, 'Thahu' - evil, 'shambas' - farms, 'trugu'. Ngugi's use of dreams and hallucinations as presentiments of doom in traditional Kenyan society is also effectively evoked in the novel and can be found in the sentence. "There shall come a people with cloths like butterflies", warns the old Gikuyu seer, Mugo Wa Kibiro. Images such as 'butterflies' are used by Ngugi to symbolize the visual attractiveness of the Whiteman.

Myth is often deeply and intensely emotional. It has most often to do with the gods, deities and creation with the essence of a belief system. Myth is the imaged embodiment of a philosophical system, the giving of form to thought and emotion; and becomes both a driving and an emotional force of a people and their definition. In oral lore it is the everlasting form of cultural values, hence its link to the gods, to the dead, to the heavens, to the forever. Mythic imagery embodies significant emotions of a people, their hopes, fears, dreams, and nightmares. History is the story of a people, their institutions, their community and for that matter constitutes the way one likes to think things happened, in the real world. For the author of The River Between, all the hero figures are considered everyman, moving through a change, a transformation, and so moving into the myth, the essence, of history. Waiyaki, the direct descendant of Mugo_wa Kibiro, becomes part of history, representative of history, embodying the culture. All these legendary heroes discussed by the novelist belong to a princely class existing in an early stage of the history of the Gikuyu people. They are depicted as those who transcend ordinary men in skill, strength, and courage. They are usually born to their role and like some Greek figures and they are of semi divine origin with extraordinary prowess and precocity. War and dangerous adventure is their normal occupation. The novelist depicted them as beings surrounded by noble peers, and are very magnanimous on the one hand to their followers or descendants and ruthless to their enemies. In addition to their prowess in battle, they are resourceful and skillful in many crafts. They are most often men of action rather than thought and live by a personal code of honour that admits of no qualification. To some problems, their responses are usually instinctive, predictable, and inevitable and accept challenge. They often courts disaster, and their traits remain a seminal influence in literature. They collaborate with immortal gods though they are mortal men who experience pain and death and create, through their own efforts, a moment's glory that survives in the memory of their descendants because of their experiences tinged with perennial freshness. 
According to new historicists, the relationship between literature and history is one of circulation, exchange, and negotiation rather than of reference or reflection. There is no single historical discourse period, instead, the critic must trace out the multiple and complexly interconnected histories that make up an age. While the connections between historical realms occur through representational exchanges, encodings and refigurations of social energy and cultural imagery that are not reductible to the terms of economic determinism or referential reflection, they can nonetheless be described as 'the reproduction and circulation of mimetic capital (Ryan, 1999: 130). A culture consists of a stockpile of accumulated stories upon which writers rely and which are crucial to the constitution and negotiation of power within the culture (Ryan, 130)

So are mythological figures presented in Ngugi's text. Mugo wa Kibiro, the hero is everyman with myth inside him for he has been mythicized; story does that. Metaphor is the transformational process, the movement from the real to the mythic and back again to the realchanged forever, because one has become mythicized, because one has moved into history and returned with the elixir. Postcolonial writers use oral power to enhance their literary grace. But orature is the product of African languages. Postcolonial theory, recalls Chessler Bressler (2007: 202) is born out of the colonised peoples' frustrations, their direct and personal cultural clashes with the conquering culture, and their fears, hopes, and dreams about the future and their own identities. To be colonised is to be removed from history (202). Therefore, all this literature is actually dependent for its identity on that which is produced by African languages. This is natural and to be expected when Africans write in African languages (Ngugi, 1999: 126). Since a storytellers' tools are not just words, but gestures, singing, facial expressions, body movements and acting to make stories memorable and interesting, Ngugi asks his readers to participate in the accounts of past deeds, beliefs, taboos (demi), and myths... Oral storytelling emphasises repetition of the language and rhythm, which are its most characteristics....

In view of the above observation, fellow readers will fervently agree with the researcher that Ngugi's effective use of simple and lucid English: short and terse sentences as well as his use of various literary devices capture his readers' interest in the novel shows that the novelist was acculturated. Ngugi is therefore undoubtedly a genius as far as novel writing and the use of literary techniques are concerned. In fact, both oral tradition and oral literature are terminologies that refer to the same corpus of material. But the former's being broader than the latter is therefore subsumed therein.

\section{Conclusion}

This paper has discussed how Ngugi abrogates and appropriates the English language, Western thought and western literary genre and makes it an African one in an effort to make it become a counter discourse in a polyglossic society. In his endeavour he shows that Kenya is not a passive entity which tolerates western onslaught; rather, she challenges western power dimension, dismantles it and imposes her own shape upon the western structure. That is why The River Between is not a novel written in a European language as well as in European form. It is rather an 
African novel written in the polyglossic context of the continent. The English used in the novel is subsequently African "English", not a "British or American" English.

In this paper, the novel of Ngugi wa Thiong'o, a literary icon of African literature in English, has been analyzed using Ashcroft et al.'s (1989) textual strategies in postcolonial writing to unearth the strategies he used in valorizing the use of an abrogated and appropriated imperial language in expressing native sentiments. It has been argued throughout this essay that the quest for knowledge and its acquisition just like all human interaction depends on and is enhanced through verbal or written forms which seem to run on parallel lines. Though they are never dichotomous; they nonetheless constitute excellent pedagogical implications in oral cultures (traditional African societies) and are more pervasive in activities in once colonised spaces. It is a fact that history and knowledge systems are located in memory, personal lives, traditions and the mythical past of all communities before printing and writing. Today literature has been associated with written forms but most cultures of the once colonised world, apart from western cultures, have produced a wide range of literary materials which are encoded in verbal or nonwritten genres. In this case oral discourses are predominant in most indigenous communities and as such knowledge systems have been constructed and communicated through these oral discourses or verbal systems, with emphasis on graphic contextual performances for a long time. In literature, African verbal forms constitute the largest stock of literary material performed, sung or spoken in numerous social or ritualistic contexts. Novels from these spaces suggest that the use of untranslated words and glossing are part and parcel of abundant strategies used to abrogate and appropriate the colonizer's language and as well incorporate the cultural sensibilities of the non-Coloniser's societies. The linguistic abrogation is the postcolonial writers' rejection of the notion of a singular, standard English. Postcolonial discourse pursues this agenda. Another strategy of conveying the sense of cultural distinctiveness is leaving the words un-translated. Sometimes such words are left un-glossed with a context to give their meaning. In postcolonial texts, this political act of leaving the words un-translated indicates that the text is written in an 'other' language. Some postcolonial writers fuse the linguistic structures of two languages generating an 'inter-culture'. Further, a blend of local language syntax with the lexical forms of English is also frequent in postcolonial writings. Code-switching is the most common strategy of appropriating the language.

Thematic analysis of the text point to four themes relating to how the Ngugi wa Thiong'o valorized the use of an English in expressing native sentiments: expression of an authentic self, expression of an authentic place, subtle form of subversion and advancement of his revolutionary identities and ideologies. Colonial experience, globalization and immigration are two shaping forces which contribute to the emergence of the indigenization of the coloniser's language (English), especially in the creative writings of former colonized countries. Today, it has been an established phenomenon that is gaining popular currency with the spread of postcolonial literatures: to appropriate the dominant language is to capture and describe the local reality and thereby make the standard English less of a language of cultural imperialism. 


\begin{abstract}
About the author
Kammampoal Bawa is an Associate Professor of African creative writing at Université de Kara, Kara, Republic of Togo, West Africa. He has lectured as a visiting professor at Université de Lomé, Lomé, the nation's capital; and has delivered numerous talks and conducted seminars with international audiences in English Language teaching, African literature: oral as well as written. He has published articles in journals and conference proceedings. He has also been instrumental in the elaboration of text-books for Togolese senior secondary schools in American studies. He is now working with doctoral students in African literature.
\end{abstract}

\title{
Bibliography
}

Al-Dabbagh, Abdulla (2010). Literary Orientalism, Postcolonialism, and Universalism. New York: Peter Lang.

Anchimbe, Eric and Stephen A. Mforteh (2011). Postcolonial Linguistic Voices: Identity Choices and Representations. Boston: De Gruyter Mouton.

Anderson, Benedict R. O'G. (2006). Imagined Communities: Reflections on the Origin and Spread of Nationalism. Rev. ed. London: New York: Verso.

Ashcroft, Bill, Gareth Griffiths, and Helen Tiffin (1989). The Empire Writes Back: Theory and Practice in Post-Colonial Literatures. New York: Routledge.

Beier, Ulli (1967). An Introduction to African Literature. Longman. Green and Co. Ltd.

Bressler, C. E. (2011/2007/2003). Literary criticism: An Introduction to theory and Practice. New York: Jersey, Prentice Hall.

Britton, Celia (1999). Edouard Glissant and Postcolonial Theory: Strategies of Language and Resistance.

Charlottesville, Va.: University Press of Virginia.

Chiwenzu, Onwuchekwa (1980). Towards the Decolonisation of African Literature. Vol. 1. Enugu:

Fourth Dimension Publishers.

Cook, D. (1977). African literature: A Critical View. London. Longman.

Cook, David, Michael, Okerimkpe (1983). Ngugi wa Thiong'o. An Exploration of his Writings. London. HEB.

Duerden, D. \& Pieterse, C. (1972). African Writers Talking. Heinemann. London.

Fanon, Franz (1967). The Wretched of the Earth. Harmondsworth. Penguin.

Finnegan, R. (1970). Oral Literature in Africa. Oxford: Clarendon.

Eme, A. C., Mbagwu, U. D. (2011). “African Languages and African Literature”. UJAH: Unizik Journal of Arts and Humanities.12 (1).

Emenajo, E. N. (2000). Culture, Nigerian Languages and National Development. JONLACK2.,110.

Ezenwa-Ohaeto (1997). Chinua Achebe: The Author of Things Fall Apart. USA: Heinemann.

Goody, Jack (1987). The Interface Between the Written and the Oral, Cambridge: Cambridge University Press, 1987.

Jones, Eldred (1972). African Literature Today. Nos. 1-4. London. Heinemann. Finnegan, Ruth (1977). Oral Poetry. Cambridge: Cambridge University Press. 
Kammampoal, Bawa (2010). “Orature in Modern Creative African Writing: Linguistic and Literary Power in Achebe's Things Fall Apart", CAMES, Sciences sociales et humaines, nouvelle série, B, (013)11. 267-278.

Killam, G. D. (1981). An Introduction to the Writing of Ngugi. London, Heinemann Educational Books Ltd.

Larson, Charles, R. (1948). The Novel and the Modern World. Chicago: The University of Chicago Press.

Larson, Charles, R. (1978). The Emergence of African Fiction. (Macmillan International Collage Edition) London and Basingstoke: The Macmillan Press Ltd.

Mcleod, J. (2000). Beginning Postcolonialism. New York: Manchester University Press.

Moody, H. L. B. (1971). The Teaching of Literature in Developing Countries. Longman Group Ltd.

Na'Ahllah, Abdul-Rashhed (2009). African Discourse in Islam, Oral Traditions, and Performance. Routledge.

Ngũgĩ wa Thiong'o (1964). Weep not Child. London: Heinemann. 1964.

Ngũgĩ wa Thiong'o (1965). The River Between London: Heinemann.

Ngũgĩ wa Thiong'o (1966). Union News (ed). Leeds University, 18 November.

Ngũgĩ wa Thiong'o (1972). Homecoming: Essays London: Heinemann.

Ngũgĩ wa Thiong'o (1977). Petals of Blood. London: Heinemann.

Ngũgĩ wa Thiong'o (1981). Decolonising the Mind: The Politics of Language in African Literature.

Portsmouth, NH: Heinemann.

Ngũgĩ wa Thiong'o (1981). Decolonising the Mind: the Politics of Language in African Literature London: Heinemann. 1981.

Ngũgĩ wa Thiong'o (1988). Penpoints, Gunpoints and Dreams. Towards a Critical Theory of the Arts and the State in Africa. Oxford: Oxford University Press.

Ngũgĩ wa Thiong'o (2007). Wizard of the Crow London: Heinemann.

Ngũgĩ wa Thiong'o (1980). Writers in Politics: Essays. London: Heinemann.

Ngũgĩ wa Thiong'o (1982). Devil on the Cross London: Heinemann. 1982.

Ngũgĩ wa Thiong'o (1997). Writers in Politics: A Re-Engagement with Issues of Literature E Society. James Currey, ed. EAEP/Heinemann.

Obi, N.M. (2003). "Language: A Tool for Literature". Ndimele(ed). Four decades in the study of languages and $\mathcal{E}$ Linguistics in Nigeria. A festschrift for Kay Williamson. Aba: NINLAND.487492.

Ogunde, J. (1999). Ngugi's Novels and African History: Narrating the Nation. London. Sterling, Va: Pluto Press.

Okpewho, Isidore (1992). African Oral literature: Backgrounds, Character and community.

Okpewho, Isidore (1989). African Poetry: The Modern Writer and the Oral Tradition. In Jones, D.J., Palmer, E. \& Jones, M. Oral and Written Literature Today. London: Currey. 1-5.

Ong, Walter J. (1982). Orality and Literacy: The Technologizing of the Word, London/New York, Methuen.

Pieterse, C., \& Munro D. (1959). Protest and Conflict in African Literature. London. Heinemann.

Ramanathan, Vaidehi (2005). The English-Vernacular Divide: Postcolonial Language Politics and Practice. Clevedon; Buffalo: Multilingual Matters. 
Rushdie, S. (1992). Imaginary Homelands. New York: Granta.

Ryan, Michael (1999). Literary Theory: A Practical Introduction. USA: Blackwell Publishing.

Schneider, Edgar W. (2007). Postcolonial English: Varieties around the World. Cambridge: Cambridge University Press.

Talib, Ismail S. (2002). The Language of Postcolonial Literatures: An Introduction. London: Routledge.

Viningoma, J. (1991). "Literacy and Orality in African Literature: The Case of Ngugi wa Thiong'o". Commonwealth. 9(2). 
Author(s) will retain the copyright of their published articles agreeing that a Creative Commons Attribution 4.0 International License (CC BY 4.0) terms will be applied to their work. Under the terms of this license, no permission is required from the author(s) or publisher for members of the community to copy, distribute, transmit or adapt the article content, providing a proper, prominent and unambiguous attribution to the authors in a manner that makes clear that the materials are being reused under permission of a Creative Commons License. Views, opinions and conclusions expressed in this research article are views, opinions and conclusions of the author(s). and European Journal of Literature, Language and Linguistics Studies shall not be responsible or answerable for any loss, damage or liability caused in relation to/arising out of conflicts of interest, copyright violations and inappropriate or inaccurate use of any kind content related or integrated into the research work. All the published works are meeting the Open Access Publishing requirements and can be freely accessed, shared, modified, distributed and used in educational, commercial and non-commercial purposes under a Creative Commons Attribution 4.0 International License (CC BY 4.0). 